\title{
Research on the changes of physiological characteristics of algal cells in the process of algae dissolving by immobilized white rot fungi
}

\author{
Guoming Zeng ${ }^{1}$, Jing Luo ${ }^{2}$, Xiaowan Liu ${ }^{1}$, Maolan Zhang ${ }^{1, *}$, and Hengjun Tang ${ }^{3, *}$ \\ ${ }^{1}$ Engineering and Architecture Department,Chongqing University of Science and Technology,Chongqing, China \\ ${ }^{2}$ Art College Department, Chongqing Technology and Business University, Chongqing, China \\ ${ }^{3}$ Engineering and Architecture Department, Sichuan University of Science and Engineering, Sichuan, China
}

\begin{abstract}
With the increasing of water pollution, water eutrophication is seriously affecting people's daily life and production. Therefore, it is particularly important to explore safe and efficient algae control technology. In the current algal bloom treatment methods, the physical method is not complete in algae dissolving, and the cost of algal control is high. The chemical method is easy to produce secondary pollution and toxic by-products, and the safety is not high. However, the biological method has the advantages of low cost, high ecological security and good ecological compatibility. It is considered to be a more promising method to remove algae and biological toxins, and it is also an inevitable trend to control water eutrophication in the future.
\end{abstract}

\section{Introduction}

White rot fungus not only can degrade water pollutants that other microorganisms can't or are difficult to degrade, especially some pollutants with aromatic ring structure and greater toxicity, but also has a strong effect on algae removal and algal toxin reduction. Therefore, it is considered to be a magic weapon in algae control technology ${ }^{[1-6]}$.

Therefore, in this paper, we take scenedesmus quadricauda as the research object, use immobilized white rot fungi to control algae, adopt response surface experimental design to optimize the algae dissolving conditions of white rot fungus control system, and make a profound study the changes of the physiological characteristics of algae dissolving, which has important application value to promote the application of this new microbial algae control technology in the treatment of actual water eutrophication.

\section{Materials and Methods}

\subsection{Strains and Medium Used in the Experiment}

Strains: CGMCC5.776-white rot fungus (Phanerochaete Chrysosporium) was purchased from Network for Microbial Strains of China. After purchase, it was cryopreserved at $-40^{\circ} \mathrm{C}$ by the research group, inoculated to PDA medium before use, cultured at $25-35^{\circ} \mathrm{C}$ for $5-7 \mathrm{~d}$, and stored at $4^{\circ} \mathrm{C}$ for standby.
PDA liquid medium: potato 200g, glucose 20g, $\mathrm{KH}_{2} \mathrm{PO}_{4}{ }^{3} 3 \mathrm{~g}, \mathrm{MgSO}_{4} .7 \mathrm{H}_{2} \mathrm{O} 1.5 \mathrm{~g}$, vitamin $\mathrm{B}_{1} 0.01 \mathrm{~g}$.

\subsection{Experimental Device}

The experimental device for controlling algae by white rot fungus is made of organic glass. The height of the reactor is $40 \mathrm{~cm}$, the inner diameter is $30 \mathrm{~cm}$, the effective volume is $20 \mathrm{~L}$, and the membrane-hanging density is $30 \%$. The membrane-hanging carrier adopts the biological carbon fiber selected in the previous research as the biomembrane carrier. The reactor is equipped with a heating constant temperature device. The constant temperature heater is used to control the temperature of the reactor to $25 \sim 35^{\circ} \mathrm{C}$, and the sequential batch operation mode of "water inlet - reaction - drainage" is adopted. The experimental device is shown in Figure 1.

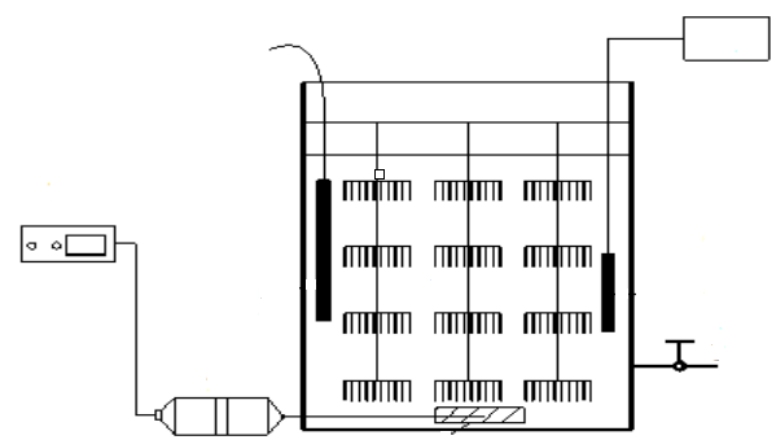

Fig. 1. experimental device

\footnotetext{
* Corresponding author: 511926581@qq.com; 


\subsection{Experimental Strain}

Scenedesmus quadricauda FACHB-507 was selected as biothe experimental strains, which were all purchased from the Algae Strain Preservation Center of Institute of Hydrology, Chinese Academy of Sciences. The culture medium formulation is provided by the Algae Strain Preservation Center of Institute of Hydrobiology, Chinese Academy of Sciences, and the detailed formula is shown in Table 1.

Table 1.The growth medium used for Scenedesmus quadricauda FACHB-507 was SE (pH 7.5).

\begin{tabular}{|c|c|c|c|}
\hline \multirow{3}{*}{$\begin{array}{c}\text { Element } \\
\mathrm{NaNO}_{3}\end{array}$} & \multirow{3}{*}{$\begin{array}{c}\begin{array}{c}\text { Content } \\
\left(\mathbf{g}^{-\mathbf{L}}\right)\end{array} \\
0.025\end{array}$} & \multicolumn{2}{|c|}{ Soil nutrient solution } \\
\hline & & Element $\mathrm{Cc}$ & ent $\left(g^{-L}\right)$ \\
\hline & & $\mathrm{H}_{3} \mathrm{BO}_{3}$ & 0.286 \\
\hline $\mathrm{NaCl}$ & 0.0025 & $\mathrm{MnCl}_{2} \cdot 4 \mathrm{H}_{2} \mathrm{O}$ & 0.181 \\
\hline $\mathrm{K}_{2} \mathrm{HPO}_{4} \cdot 3 \mathrm{H}_{2} \mathrm{O}$ & 0.0075 & $\mathrm{ZnSO}_{4} \cdot 7 \mathrm{H}_{2} \mathrm{O}$ & 0.0022 \\
\hline $\mathrm{MgSO}_{4} \cdot 7 \mathrm{H}_{2} \mathrm{O}$ & 0.0075 & $\mathrm{CuSO}_{4} \cdot 5 \mathrm{H}_{2} \mathrm{O}$ & 0.0079 \\
\hline $\mathrm{CaCl}_{2} \cdot 2 \mathrm{H}_{2} \mathrm{O}$ & 0.0025 & $\mathrm{Na}_{2} \mathrm{MoO}_{4} \cdot 2 \mathrm{H}_{2} \mathrm{O}$ & 0.0039 \\
\hline $\mathrm{KH}_{2} \mathrm{PO}_{4}$ & 0.0175 & $\mathrm{CoCl}_{2} \cdot 6 \mathrm{H}_{2} \mathrm{O}$ & 0.0020 \\
\hline $\mathrm{Fecl}_{3} \cdot 6 \mathrm{H}_{2} \mathrm{O}$ & 0.0005 & & \\
\hline EDTA-Na & 0.0002 & & \\
\hline $\begin{array}{l}\text { Soil extract } \\
\text { solution }\end{array}$ & $40 \mathrm{ml}^{-\mathrm{L}}$ & & \\
\hline
\end{tabular}

Culture conditions: temperature $(25 \pm 1)^{\circ} \mathrm{C}$, light intensity of 2000lx - 25001x, light dark ratio of $12 \mathrm{~h}: 12 \mathrm{~h}$, standing culture, regular shaking 3 times a day, so that the growth of algae cells in the same medium tends to the same stage, and the experiment is carried out after the normal microscopic examination of cells.

\subsection{Experimental Method}

\subsubsection{Response Surface Experimental Design}

In the research of white rot fungi treating single dominant algal strains in eutrophic water, three factors of response surface experiment design are selected in this paper, i.e. dosage of white rot fungi, dissolved oxygen (DO) and hydraulic retention time (HRT). The algae dissolving experiment of white rot fungi is carried out according to the response surface experiment design of three factors and three levels, as shown in Table 2.

Table 2. Variables and levels in RSM of Scenedesmus quadricauda FACHB-507

\begin{tabular}{|c|c|c|c|}
\hline \multirow{2}{*}{ Element } & \multicolumn{3}{|c|}{ level } \\
\cline { 2 - 4 } & -1 & 0 & 1 \\
\hline A-Dosage of white rot fungi(mg/L) & 150 & 200 & 250 \\
\hline B-DO (mg/L) & 6 & 7 & 8 \\
\hline C-HRT(h) & 36 & 48 & 50 \\
\hline
\end{tabular}

\subsection{Experimental Method}

Chlorophyll a was determined by acetone method ${ }^{[7]}$. The dehydrogenase activity of algal cells was determined by triphenyltetrazolium chloride dehydroge- nase reduction method [8]. The content of soluble protein was determined by Coomassie brilliant blue-G250 method.

\subsection{Statistical Analysis Method}

The experimental data were analyzed and processed by Origin 8.0 software processing system, Design-ExPert 8.0, DPS7.5 data processing system software and Windows Excel, Word (2003, 2010 version) office software.

\section{Experimental Results and Discussion}

\subsection{Membrane-hanging and Acclimation}

The method of membrane-hanging and acclimation was used simultaneously. 20L of water samples of cryptoalgae cultured in the laboratory were pumped into the sterilized reactor, $15 \%$ of the suspension of white rot fungus was put into the reactor and kept in oxygen. The dissolved oxygen in the water was controlled to be $5.0-7.0 \mathrm{mg} \cdot \mathrm{L}-1$, and the membrane-hanging and acclimation was conducted at $30-35^{\circ} \mathrm{C}$. Each liter of mixed algal water medium contains $0.4 \mathrm{~g}$ glucose, $0.1 \mathrm{~g}$ ammonium tartrate, $0.5 \mathrm{~g}$ sodium acetate, $10 \mathrm{ml}$ nutrient $\operatorname{salt}\left(3.0 \mathrm{~g} / \mathrm{L} \mathrm{KH}_{2} \mathrm{PO}_{4}{ }^{3}, 4.0 \mathrm{~g} \cdot \mathrm{L}-1 \mathrm{MgSO}_{4} \cdot 7 \mathrm{H}_{2} \mathrm{O}, 1.0 \mathrm{~g} \cdot \mathrm{L}-1\right.$ $\mathrm{CaCL}_{2}$, 0.5.0 $\mathrm{g} \cdot \mathrm{L}-1 \quad \mathrm{NH}_{4} \mathrm{CL}, 10.0 \mathrm{mg}$ vitaminB ${ }_{1}$ ). By observing the changes of biofacies on the surface of biological carbon fiber, it was found that biomembrane appeared on the surface of filler on the second day, white rot fungi grew well on the third day, chlorophyll a in on the fifth day, indicating that the process of membrane-hanging and acclimation had been completed, and the system had entered a running state. water samples decreased significantly on the fourth day, and chlorophyll a in water samples entered a stable state

\subsection{Response Surface Experiment}

Take the algae dissolving rate as the response value, and carry out the algae dissolving experiment of white rot fungus treatment according to the response surface design experimental scheme. The experimental results are shown in Table 3, and Table 4. 
Table 3. Experimental design and response in RSM of Scenedesmus quadricauda FACHB-507

\begin{tabular}{|c|c|c|c|c|}
\hline \multirow{2}{*}{ Sources code } & \multicolumn{3}{|c|}{ Element } & algae dissolving Rate \\
\cline { 2 - 5 } & $\mathrm{A}$ & $\mathrm{B}$ & $\mathrm{C}$ & $\mathbf{( \% )}$ \\
\hline 1 & 200 & 7 & 48 & 90.56 \\
\hline 2 & 200 & 6 & 36 & 84.21 \\
\hline 3 & 200 & 8 & 36 & 88.68 \\
\hline 4 & 150 & 7 & 50 & 78.52 \\
\hline 5 & 150 & 7 & 36 & 76.35 \\
\hline 6 & 200 & 7 & 48 & 89.67 \\
\hline 7 & 200 & 7 & 48 & 89.82 \\
\hline 8 & 250 & 7 & 50 & 90.67 \\
\hline 9 & 150 & 6 & 48 & 78.23 \\
\hline 10 & 150 & 8 & 48 & 80.58 \\
\hline 11 & 250 & 7 & 36 & 88.87 \\
\hline 12 & 200 & 8 & 50 & 90.15 \\
\hline 13 & 250 & 8 & 48 & 88.86 \\
\hline 14 & 250 & 6 & 48 & 87.53 \\
\hline 15 & 200 & 6 & 50 & 88.52 \\
\hline
\end{tabular}

Table 4. ANOVA analysis for regression equation

\begin{tabular}{|c|c|c|c|c|c|c|}
\hline Sources & Df & Sum & Csf & Cv. & F & p \\
\hline regression & 9 & 354.224 & 354.224 & 39.3583 & 24.98 & 0.0012 \\
\hline linear & 3 & 246.972 & 78.406 & 26.1354 & 16.59 & 0.005 \\
\hline square & 3 & 104.942 & 104.942 & 34.9807 & 22.20 & 0.003 \\
\hline interact & 3 & 2.311 & 2.311 & 0.7702 & 0.49 & 0.705 \\
\hline Residual error & 5 & 7.879 & 7.879 & 1.5758 & & \\
\hline lack of fit & 3 & 7.425 & 7.425 & 2.4750 & 10.90 & 0.085 \\
\hline Pure error & 2 & 0.454 & 0.454 & 0.2270 & & \\
\hline sum & 14 & 362.104 & & & & \\
\hline
\end{tabular}

Taking algae dissolving rate $\mathrm{Y}$ as the response value, A (dosage of white rot fungus), B (DO) and C (hydraulic retention time) as independent variables, and after the treatment of Design-Expert.8.0 software, the multiple quadratic regression equation of the response surface factors and the algae dissolving rate of white rot fungi treating scenedesmus quadricauda was obtained:

$\mathrm{Y}=90.02+5.28 * \mathrm{~A}+1.22 * \mathrm{~B}+1.22 * \mathrm{C}-0.25 * \mathrm{~A} * \mathrm{~B}-0.093 *$

$$
\mathrm{A} * \mathrm{C}-0.71 * \mathrm{~B} * \mathrm{C}-5.25 * \mathrm{~A}^{2}-0.96 * \mathrm{~B} 2-1.16 * \mathrm{C}^{2}
$$

The results in Table 4 show that the $\mathrm{F}$ value of 24.98 is a low probability value, $\mathrm{P}$ is $0.0012<0.05$, indicating that the model is highly significant; When the Dosage of white rot fungus is $200-250 \mathrm{mg} / \mathrm{L}$, HRT is $48-50 \mathrm{~h}$, and Do is $7 \mathrm{Mg} / \mathrm{L}-8 \mathrm{mg} / \mathrm{L}$, the algae dissolving rate is the highest. According to the analysis of Design-ExPert 8.0 software, the optimal conditions are: the dosage of white rot fungus is $250 \mathrm{mg} / \mathrm{L}$, DO $8 \mathrm{mg} / \mathrm{L}$, HRT $48 \mathrm{~h}$, and the maximum theoretical value $(\mathrm{Y})$ of algae dissolving is $90.02 \%$.

\section{Conclusion}

Response surface design method was used to optimize the optimal conditions of the algal control system of white rot fungus for the treatment of four tailed Scenedesmus: under the optimal conditions of the dosage of white rot fungus $250 \mathrm{mg} / \mathrm{L}, \mathrm{DO} 8 \mathrm{mg} / \mathrm{L}$ and HRT $48 \mathrm{~h}$, the algae dissolving rate, DHA reduction rate and soluble protein reduction rate were $85.48 \%, 59.23 \%$, $65.16 \%$ and MDA content $0.128 \mathrm{umol} / \mathrm{L}$, respectivel.

This work was supported by the National Natural Science Foundation (51808086); Chongqing Science and Technology Commission Project (cstc2018jcyjAX007 8); Scientific Research Funding Project of Chongqing Unive rsity of Science and Technology, (ckrc2019015); Graduate Science and Technology Innovation Program Project of Chongqing University of Science and Technology (YKJCX1920617).

\section{References}

1. N. John, A.V. Koehler, B.R.E. Ansell, L. Baker, N.D. Crosbie, A.R. Jex, Wat. Res. 136 (2018)

2. N. Imamura, I. Motoike, N. Shimada, H. Nishikori, H. Fukami, Jou. Ant 54, 7 (2001)

3. Q. Jin, S.L. Dong, Jou. Exp. Mar. Bio. Eco 293 (2003)

4. E.H. Hashimoto, H. Kato, Y. Kawasaki, Y. Nozawa, 
K. Tsuji, E.Y. Hirooka, K. Harada, Che. Res. Tox 22 (2009)

5. K. Tsuji, M. Asakawa, Y. Anzai, T. Sumino, K. Harada, Che 65 (2006)

6. G .M. Zeng,P. Wang, Y. Wang, Alg. Res. Bio 12 (2015)

7. G.M. Zeng, P. Wang, T. Huang, Xianhui Song, Asi. Jou. of Che 26,8 (2014)

8. J. Xie, W.R. Hu, H.Y. Pei, Env. Mon. Ass 146 (2008) 